УДК 339.138:378

DOI: https://doi.org/10.26642/jen-2019-4(90)-100-104

Т.А. Ящук, к.е.н., ст. викладач

Уманський державний педагогічний університет імені Павла Тичини

\title{
Особливості маркетингу освітніх послуг закладу вищої освіти
}

Освітню діяльність можна розглядати як сукупність бізнес-процесів, оскільки з'явилася можливість поставити ї̈ на потік $i$, завдяки цзьому, забезпечити масовість освіти, необхідну для розвитку суспільства. Проте ще належить вирішувати проблеми пошуку оптимального поєднання форм і технологій навчання, щзо дозволяє оптимізувати освітній процес $i$ знизити витрати на його організацію. Одним із можливих рішень є освітній маркетинг, здатний забезпечити ефективність діяльності ВНЗ на сучасному етапі. Існування і розвиток закладу вищої освіти безпосередньо залежить від кількості студентів, яка, в свою чергу, залежить від успішності маркетингової діяльності освітньої установи. У результаті чого проявляється притаманний всім господарюючим суб'єктам комплементарний зв'язок між маркетинговою $i$ фінансовою діяльністю. Формування сучасної комплексної маркетингової інформаційної моделі закладу вищої освіти дозволяе застосувати ї̈ для вирімення иілого ряду завдань на ринку освітніх послуг і успішно конкурувати з іншими вузами. Ї̈ використання не тільки дозволить упорядкувати роботу освітнього закладу в сфері залучення абітурієнтів, а й сприятиме інтеграції маркетингових інформаційних систем, застосування яких дозволить оптимізувати ринкову стратегію навчального закладу. Все ие дозволяє зробити висновок про збереження високої актуальності досліджень у сфері маркетингу закладів вищої освіти. Розуміння сутності маркетингу освітніх послуг $\epsilon$ передумовою розробки ефективного комплексу маркетингових заходів для вузів і успішності їх діяльності. Сучасний ринок освітніх послуг вимагає від закладів вищої освіти безперервного вдосконалення діяльності: постійного освоєння нових технологій (дистанційне навчання), розширення співпраці з іноземними освітніми установами (Болонська система), розробки додаткових навчальних курсів, підготовки та сприяння в участі у професійних конференціях. Тому конщепџія маркетингу освітніх послуг полягає в створенні такого продукту, який максимально відповідає потребам сьогодення $i$ враховує вимоги майбутніх поколінь на основі впровадження досягнень науки світового рівня та інновачійних технологій навчання.

Ключові слова: заклади вищої освіти; освітні послуги; маркетинг освітніх послуг; маркетингова діяльність.

Актуальність теми. У даний час освіта $є$ одним із основних факторів і ресурсів економічного й соціального розвитку. Рівень освіти населення країни є одним із найважливіших умов підвищення добробуту суспільства, забезпечення конкурентоспроможності й розвитку національної та регіональної економік. Зниження чисельності потенційних споживачів освітніх послуг, мобільність абітурієнтів вилилося у загострення конкурентної боротьби між вузами, особливо це торкнулося регіональних ринків освітніх послуг. В умовах конкуренції ВНЗ стає суб'єктом ринкової економіки і є товаровиробником освітніх послуг. Це вимагає формування нового механізму функціонування освітнього закладу, адекватних підходів до оцінки ефективності його діяльності з урахуванням економічних і якісних результатів. Для того щоб виграти в конкурентній боротьбі на ринку освітніх послуг, вузам необхідно впроваджувати механізми маркетингу в систему управління.

Аналіз останніх досліджень та публікації, на які спирасться автор. Дослідженням маркетингу освітніх послуг займалися такі вітчизняні та зарубіжні вчені: С.М. Андрєєв, В.Афанасьєва, С.В. Білоусова, М.М. Волкова, А.М. Гвозденко, О.В. Дубровка, Ю.Кіріліна, Е.А. Клусова, Н.Литвинова, І.О. Маштакова, А.Ю. Могилова, Ю.Б. Миронов, Т.Є. Оболенська, О.П. Панкрухин, Є.Н. Попова, І.В. Решетнікова, С.В. Ткачук, Д.А. Шевченко та ін.

Метою статті є дослідження сутності та особливостей маркетингу освітніх послуг, його ролі у підвищенні конкурентоспроможності сучасних закладів вищої освіти.

Викладення основного матеріалу. Освіта $\epsilon$ однією 3 найбільш динамічно зростаючих перспективних сфер економіки. Освіта сьогодні - це нова пошукова сфера маркетингу, спрямована на виявлення та ранжування потреб і залишається для сучасного індивіда пріоритетною соціальною потребою.

Ринок освітніх послуг як соціально-економічна система - це сукупність соціально-економічних відносин, що складаються у товарному освітньому виробництві між усіма суб'єктами як по горизонталі, так і по вертикалі (навчальними закладами всіх типів, споживачами освітніх послуг, споживачами робочої сили, державою і різними зацікавленими організаціями) з приводу купівлі-продажу освітніх

(C) Т.А. Ящук, 2019 
послуг. Товаром на ринку освітніх послуг є знання, вміння та навички, пропоновані суб'єктами цього ринку (вузами, приватними викладачами, училищами, коледжами тощо).

Відповідно до класичної теорії маркетингу, послугам притаманний ряд специфічних характеристик, що відрізняють їх від товару і які необхідно враховувати при розробці маркетингових програм. Ці характеристики такі:

1) невідчутність (послуги неможливо побачити, спробувати на смак, почути до моменту придбання);

2) невід'ємність від джерела (послуга невід'ємна від свого джерела, їі здійснення можливе тільки в присутності виробника);

3) мінливість якості (якість послуг коливається в широких межах залежно від їх виробників, а також від часу і місця їх надання);

4) незбереженість (послугу неможливо зберігати для подальшого продажу або використання) [1, с. 40].

Маркетинг освітніх послуг - це наука, що вивчає ринок платних освітніх послуг; діяльність 3 їх розподілу і просування; філософія освітнього бізнесу. Застосування маркетингу дає можливість кожному освітньому закладу відстежувати ситуацію на ринку праці і відповідно до неї коригувати обсяг і якість освітніх послуг. Метою маркетингу освітніх послуг є формування умов розвитку системи освіти, яка забезпечить задоволення освітніх потреб особистості і суспільства в цілому з урахуванням потреб регіонального ринку праці; збереження і розвиток системи освіти в умовах ринку.

Сутність маркетингу освітніх послуг полягає в максимальному задоволенні індивідуальних потреб споживачів освітніх послуг щодо особистого та професійного зростання та підвищенні особистої цінності людини, внаслідок чого відбувається відтворення загального інтелектуального потенціалу суспільства. Тому дослідження споживачів - безпосередніх одержувачів освітніх продуктів - $є$ основою маркетингу освіти [2, с. 23].

3 точки зору маркетингу у функції освітнього закладу входить:

- надання освітніх послуг споживачам, передача необхідних знань, умінь і навичок (як за змістом та обсягом, так і за асортиментом і якістю);

- виробництво та надання додаткових освітніх послуг, що формують особистість майбутнього фахівця;

- надання інформаційно-посередницьких послуг потенційним i реальним споживачам та роботодавцям, включаючи узгодження з ними умов майбутньої роботи, розмірів, порядку і джерел фінансування освітніх послуг та ін.

Основними об'єктами маркетингу освітніх послуг є товари і послуги, також це можуть бути установи, території та окремі особистості. Важливу роль серед суб'єктів маркетингу освітніх послуг відіграє особистість самого студента, оскільки він $є$ матеріальним носієм освітніх послуг, а також їх кінцевим споживачем.

Маркетинг освітніх послуг має ряд особливостей, зумовлених специфікою самої послуги і сфери освіти в цілому, серед яких головними є: активна роль кінцевого споживача освітніх послуг; відстрочений характер виявлення результатів надання освітніх послуг; пріоритет співпраці і обмеження ефективності конкуренції виробників освітніх послуг; особлива роль і значущість держави в освітній сфері, а також необхідність його участі в розвитку освіти.

Головними завданнями освітнього маркетингу на даний момент є:

- дослідження ринку праці регіону для визначення найбільш затребуваних професій і перспектив розвитку даних потреб у зв'язку з реструктуризацією економіки;

- вивчення ринку освітніх послуг, запитів споживачів цих послуг;

- пошук потенційних споживачів освітніх послуг;

- створення у ЗВО умов постійної адаптації до соціального запиту регіону на фахівців за профілями;

- врахування геополітичного положення регіону для визначення оптимальної стратегії у маркетинговій політиці;

- організація управлінням вузу для максимального задоволення запитів споживачів освітніх послуг.

Центральне місце в маркетингу сфери освіти займає розробка комплексу маркетингу - це сукупність взаємопов'язаних і взаємодоповнюючих факторів маркетингу, які установа використовує для досягнення бажаних змін параметрів цільового ринку.

Основними складовими комплексу маркетингу є:

1. Послуга як товар: асортимент освітніх послуг $є$ досить широким, постійно і інтенсивно оновлюється, враховуючи вимоги клієнтів, суспільства, науково-технічного прогресу.

2. Ціна послуги: ціни на освітні послуги формуються під впливом ринку, величини платоспроможного попиту; ціна може використовуватися також для позиціонування послуги.

3. Канали розподілу послуг: сукупність незалежних організацій, залучених у процесі задоволення попиту на послуги, роблять їх доступними для споживачів.

4. Система просування послуг на ринок: діяльність 3 просування спрямована на конкретні цільові групи споживачів освітніх послуг, на можливих посередників. 
До основних інструментів системи просування на ринку освітніх послуг належать: реклама як будьяка оплачена форма неособистого представлення і просування освітніх послуг чітко визначеним рекламодавцем; стимулювання збуту як система короткочасних спонукальних заходів і прийомів заохочення покупки або продажу освітньої послуги; персональні продажі як усне уявлення освітніх послуг під час бесіди з одним або декількома потенційними покупцями з метою здійснення їх продажу; зв'язки з громадськістю як заплановані тривалі зусилля, спрямовані на створення і підтримку відносин освітнього закладу з різними верствами громадськості.

Одним 3 важливих чинників маркетингу освітніх послуг є маркетингові комунікації. До системи комунікацій у маркетингу належать засоби і процеси надання споживачу інформації про ринок і пропоновану послугу. Традиційно в комплекс таких комунікацій входять реклама; бренд установи, громадська думка про заснування, про якість послуг, про працевлаштування, особисті контакти. У даний час маркетингові комунікації у сфері застосування інформаційних технологій широко трансформуються в інтегровані маркетингові комунікації - це концепція спільного використання всіх видів маркетингових комунікацій, виходячи з головних цілей. Окремі комунікації при цьому доповнюють одна одну, що створює синергетичний ефект, який підвищує якість маркетингових освітніх послуг.

Розроблення ефективної маркетингової стратегії закладами освіти має базуватися на класичному алгоритмі стратегічного планування, втім враховувати специфіку послуги, що надається. Після цього необхідно розробити дієву стратегію STP-маркетингу та, відповідно до неї, сформувати маркетинговий комплекс [3, с. 39].

Маркетизація діяльності університетів є частиною нового лібертаріанського підходу, поширення якого в державній політиці країн світу призводить до скорочення частки держбюджетного (публічного) фінансування університетів. Це змушує університети активніше пропонувати платні послуги, і не тільки освітні, а й у сфері досліджень та консультування. Тобто, ринок університетських послуг не тільки зростає, але й продуктово диверсифікується. I все це вимагає відповідного розвитку маркетингової функції на рівні університету. Університетам потрібен новий маркетинг, адже відбувається маркетизація (тобто, закони ринку стають визначальними i зумовлюють майбутній розвиток університету) i комодизація вищої освіти (розгляд iï як ринкового товару, з застосуванням традиційних для аналізу товарних ринків підходів з метою вибору економічно обгрунтованої стратегії розвитку університету). Як наслідок, у XXI ст. виклики глобального ринку вищої освіти створюють контекст нового маркетингу університетів [4].

Маркетингова діяльність вищого навчального закладу - це набір інструментів, які поєднуються на сучасному ринку освітніх послуг між споживачами освітньої послуги та вищими навчальними закладами, дозволяють сформувати ставлення до закладу, затвердити свої переваги серед конкурентів, щорічно інформувати споживачів про інновації, престиж закладу, корисність та дозволяють розробити ефективну комунікаційну стратегію ВНЗ. Маркетингова діяльність закладу вищої освіти складається 3 таких видів активності: рекламування закладу; створення його іміджу; інформування, утримання потенційних споживачів та їх батьків; залучення абітурієнтів, дослідження ринку [5, с. 298].

У даний час актуальність застосування маркетингу в галузі управління діяльністю ВНЗ не викликає сумніву. В умовах негативної демографічної ситуації та мобільності абітурієнтів, вузам необхідно вести активну і продуману маркетингову політику. Для цього необхідно створювати відповідну службу в системі управління. Основними завданнями і функціями маркетингової служби вузу мають бути:

1. Дослідження чинників, що визначають структуру і динаміку споживчого попиту на послуги ЗВО.

2. Вивчення кон'юнктури регіонального ринку освітніх послуг.

3. Аналіз внутрішнього середовища вузу (дослідження інноваційного потенціалу, науково-освітньої діяльності, рівня підготовки професорсько-викладацького складу, організаційної структури, культури і способу вузу).

4. Дослідження стратегії конкурентів.

5. Дослідження регіонального ринку потенційних споживачів освітніх послуг.

6. Дослідження регіонального ринку праці з метою вивчення потреби у фахівцях, які випускаються.

7. Організація реклами та стимулювання збуту освітніх послуг.

8. Проведення профорієнтаційної роботи серед випускників шкіл, технікумів - потенційних споживачів освітніх послуг.

9. Розробка фірмового стилю вузу.

3 точки зору просування вузу найбільш важливими є такі елементи маркетингових комунікацій: реклама, зв'язки з громадськістю, спеціальні події, прямий маркетинг, виставкова діяльність, електронні корпоративні комунікації, брендинг, корпоративна культура і корпоративний стиль. Прямий маркетинг також є одним 3 методів просування та продажу освітніх послуг. Прямий маркетинг - це адресна комунікація і організувати іiі слід як взаємодію вузу та індивіда. Для здійснення такої взаємодії використовують: особисті продажі, які дають ефективний результат при особистій взаємодії співробітника вузу з представниками цільової аудиторії; директ-мейл, який використовує персональні 
електронні адреси для розсилки рекламних інформаційних повідомлень вузу. Можлива також організація крос-промоушен освітніх послуг вусамому вузі, наприклад, для просування послуг додаткової освіти.

Для того щоб здійснювати маркетингову діяльність у навчальному закладі, необхідно розробити та реалізувати рекламну кампанію, яка $є$ сукупністю заходів, що спрямовані на досягнення конкретної маркетингової мети. Для ії досягнення необхідно сформувати в очах суспільства стійкий позитивний імідж освітнього закладу, посилити роль інформаційної реклами освітніх послуг, організувати ефективну кампанію, щоб зацікавити абітурієнтів та їхніх батьків в отриманні освітніх послуг і визначити рейтинг ЗВО на ринку освітніх послуг. Реклама освітнього закладу має містити більше, ніж просте перерахування складу освітніх послуг. Споживач даних послуг йде до закладу вищої освіти із бажанням отримати певний набір знань, умінь і можливостей, тому саме цей набір факторів і повинен становити предмет реклами [6, с. 175].

Особлива роль у маркетингу в сфері освіти віддається державі. Вона здійснює правовий захист суб'єктів маркетингових відносин від монополізму, а також від несумлінності в бізнесі та рекламі [7, с. 188]. Держава в маркетингу освітніх послуг виконує двояку роль. 3 одного боку - формує базові риси асортименту освітніх послуг, встановлює переліки спеціальностей, розробляє освітні стандарти на всіх навчальних рівнях і проводить державну акредитацію навчальних закладів. 3 другого - держава $\epsilon$ об'єктом маркетингових зусиль освітніх закладів у боротьбі за державне замовлення на підготовку фахівців певної кваліфікації. Без активної підтримки держави неможливе здійснення великомасштабних реформ галузі, спрямованих на підвищення якості і доступності освітніх послуг, а також скорочення розбіжностей між показниками попиту та пропозиції ринку освітніх послуг.

На сьогодні для успішного просування вузу необхідно розробляти цілісну систему інтегрованих маркетингових комунікацій, об'єднувати комунікаційні ресурси різних технологій просування. Одним 3 важливих питань освітніх установ в умовах ринкової економіки є їх конкурентоспроможність. Оцінка конкурентоспроможності освітнього продукту (послуги) повинна представляти комплексне дослідження ринку методами сучасного маркетингу, що дозволить правильно оцінити місце аналізованого об'єкта на даному ринку в зіставленні 3 аналогічними оцінками реальних і можливих суб'єктів ринку освітніх послуг. Керівництво університету має розробити ефективні маркетингові стратегії, які необхідні для побудови авторитетного університетського бренда, що заснований на високій якості освітніх послуг, які надаються викладачами [8, с. 119].

Висновки та перспективи подальших досліджень. Процес реформування національної системи вищої освіти в Україні та скорочення кількості абітурієнтів призвели до загострення конкуренції між закладами вищої освіти, що в свою чергу підвищило актуальність проблеми використання маркетингових стратегій провадження освітньої діяльності. Для ефективного функціонування закладів вищої освіти та коректного просування освітніх послуг на ринок необхідно мати чітке уявлення про основних конкурентів, своєчасно виділяти, утримувати і демонструвати конкурентні переваги у зовнішньому середовищі. Подальші дослідження будуть спрямовані на дослідження впливу маркетингових інструментів на підвищення конкурентоспроможності закладу вищої освіти в умовах нестабільного ринку освітніх послуг.

\section{Список використаної літератури:}

1. Білоусова С.В. Маркетинг освітніх послуг: стан, тенденції та перспективи / С.В. Білоусова // Бізнеснавігатор. - 2015. - № 1 (36). - С. 39-43.

2. Могилова А.Ю. Особливості маркетингу на ринку освітніх послуг / А.Ю. Могилова, І.В. Решетнікова // Науковий вісник Ужгородського національного університету. - 2016. - Вип. 10, Ч. 2. - С. 21-25.

3. Ткачук С.В. Маркетинг освітніх послуг: проблеми та перспективи / C.B. Ткачук, С.А. Стахурська, B.О. Стахурський // Наукові праці Національного університету харчових технологій. - 2018. - № 1, Т. 24. C. 37-47.

4. Павленко О. Маркетинг у сфері вищої освіти в XXI столітті: еволюція чи революція? / О.Павленко [Електронний ресурс]. - Режим доступу http://www.ir.kneu.edu.ua/bitstream/handle/2018/31136/IP_19_46.pdf?sequence=1\&is Allowed=y.

5. Маштакова I.O. Маркетинг освітніх послуг: сутність та методи оцінки ефективності / I.O. Маштакова // Економічні інновації. - 2015. - Вип. № 60, Кн. І. - С. 293-301.

6. Гончарова О.В. Маркетинг на ринку освітніх послуг / О.В. Гончарова // Вчені записки університету «Крок». - 2018. - Вип. 49. - С. 169-178.

7. Лукащук О.С. Особливості маркетингової діяльності у сфері освітніх послуг / О.С. Лукащук, О.В. Гончарова // Вісник Харківського національного педагогічного університету імені Г.С. Сковороди. 2013. - Вип. 40 (1). - С. 182-192.

8. Roskosa A. Marketing in higher education in the agenda of increasing international enrolment / A.Roskosa, Yu. Stukalina // Rural environment. Education. Personality. - 2019. - Vol. 12. - P. 119-125.

9. Stefko R. The Role of e-marketing tools in constructing the image of a higher education institution / R.Stefko, R.Fedorko, R.Bacik // Procedia. Social and Behavioral Sciences. - 2015. - Vol. 175. - P. 431-438. 
10. Keys of educational marketing / A.G. Tahir, S.A.A. Rizvi, M.B. Khan, F.Ahmad // Journal of Applied Environmental and Biological Sciences. - 2017. - № 7 (1). - P. 180-187.

11. Снісарчук I.B. Закономірності управління маркетинговим потенціалом закладів вищої освіти / I.B. Снісарчук // Економіка, управління та адміністрування. - 2019. - № 3 (89). - С. 87-93.

12. Жегус O.В. Ринок послуг вищої освіти як основа маркетингової діяльності вищого навчального закладу / O.В. Жегус // Економічна стратегія і перспективи розвитку сфери торгівлі та послуг. - 2017. - Вип. 1 (25). C. 269-281 [Електронний ресурс]. - Режим доступу : http://elib.hduht.edu.ua/jspui/handle/123456789/1820.

13. Лялюк $A$. Особливості використання стратегічного маркетингу вищими навчальними закладами / A.Лялюк // Економічний часопис Східноєвропейського національного університету імені Лесі Українки. Розділ III. Економіка та управління підприємствами. - 2018. - № 4. - С. 70-78.

\section{References:}

1. Bilousova, S.V. (2015), «Marketynh osvitnikh posluh: stan, tendentsii ta perspektyvy», Biznes-navihator, Vol. 1 (36), pp. 39-43.

2. Mohylova, A.Yu. and Reshetnikova, I.V. (2016), «Osoblyvosti marketynhu na rynku osvitnikh posluh», Naukovyi visnyk Uzhhorodskoho natsionalnoho universytetu, Vol. 10 (2), pp. 21-25.

3. Tkachuk, S.V., Stakhurska, S.A. and Stakhurskyi, V.O. (2018), «Marketynh osvitnikh posluh: problemy ta perspektyvy», Naukovi pratsi Natsionalnoho universytetu kharchovykh tekhnolohii, Vol. 1 (24), pp. 37-47.

4. Pavlenko, O. (2019), Marketynh u sferi vyshchoi osvity v XXI stolitti: evoliutsiia chy revoliutsiia?, [Online], available at: http://www.ir.kneu.edu.ua/bitstream/handle/2018/31136/IP_19_46.pdf?sequence=1\&is Allowed=y

5. Mashtakova, I.O. (2015), «Marketynh osvitnikh posluh: sutnist ta metody otsinky efektyvnosti», Ekonomichni innovatsii, Vol. 60 (I), pp. 293-301.

6. Honcharova, O.V. (2018), «Marketynh na rynku osvitnikh posluh», Vcheni zapysky universytetu «Krok», Vol. 49, pp. $169-178$

7. Lukashchuk, O.S. and Honcharova, O.V. (2013), «Osoblyvosti marketynhovoi diialnosti u sferi osvitnikh posluh», Visnyk Kharkivskoho natsionalnoho pedahohichnoho universytetu imeni H.S. Skovorody, Vol. 40 (1), pp. 182-192.

8. Roskosa, A. and Stukalina, Yu. (2019), «Marketing in higher education in the agenda of increasing international enrolment», Rural environment. Education. Personality, Vol. 12, pp. 119-125.

9. Stefko, R., Fedorko, R. and Bacik, R. (2015), «Role of e-marketing tools in constructing the image of a higher education institution», Procedia. Social and Behavioral Sciences, Vol. 175, pp. 431-438.

10. Tahir, A.G., Rizvi, S.A.A., Khan, M.B. and Farooq, Ahmad (2017), «Keys of educational marketing», Journal of Applied Environmental and Biological Sciences, Vol. (1), pp. 180-187.

11. Snisarchuk, I.V. (2019), «Zakonomirnosti upravlinnia marketynhovym potentsialom zakladiv vyshchoi osvity», Ekonomika, upravlinnia ta administruvannia, Vol. 3 (89), pp. 87-93.

12. Zhehus, O.V. (2017), «Rynok posluh vyshchoi osvity yak osnova marketynhovoi diialnosti vyshchoho navchalnoho zakladu», Ekonomichna stratehiia i perspektyvy rozvytku sfery torhivli ta posluh, Vol. 1 (25), pp. 269-281, [Online], available at: http://elib.hduht.edu.ua/jspui/handle/123456789/1820

13. Lialiuk, A. (2018), «Osoblyvosti vykorystannia stratehichnoho marketynhu vyshchymy navchalnymy zakladamy», Ekonomichnyi chasopys Skhidnoievropeiskoho natsionalnoho universytetu imeni Lesi Ukrainky. Rozdil III. Ekonomika ta upravlinnia pidpryiemstvamy, Vol. 4, pp. 70-78.

Ящук Тетяна Анатоліївна - кандидат економічних наук, старший викладач кафедри маркетингу, менеджменту та управління бізнесом Уманського державного педагогічного університету імені Павла Тичини.

ORCID: https://orcid.org/0000-0001-7359-5867

Наукові інтереси:

- функціонування ринку освітніх послуг.

E-mail: tetyanayashchuk@ukr.net. 